\title{
De terugkeer van Alledaags Racisme
}

Een gesprek met Philomena Essed over alledaags racisme, wetenschap en activisme

Julian Schaap en Philomena Essed

SOC 13 (1): 93-108

DOI: 10.5117/SOC2017.1.SCHA

\begin{abstract}
In recent societal debates on racism in the Netherlands, cultural anthropologist Philomena Essed has become one of the key faces of Dutch research on racism. Over three decades ago, Essed published a monograph entitled Alledaags Racisme (Everyday Racism), which gave rise to substantial debate within and beyond academia on the existence of racism - especially of a more implicit, everyday variation - in the Netherlands. For the first time since 1984, Alledaags Racisme is granted a new edition and has arguably only gained in relevance in a time when issues regarding race-ethnicity are increasingly politicized (e.g. the 'Black Pete' debate; ethno-racial profiling by police forces). Discussing - but also going beyond - this debate, this article reports a conversation between Julian Schaap and Essed on contemporary everyday racism, the sociology of race-ethnicity, and the epistemology and methodology of research that is distinctly political.
\end{abstract}

\section{$1 \quad$ Introductie}

Er zijn weinig terugkerende thema's in het Nederlandse debat zo indicatief voor de toegenomen polarisatie en identiteitspolitiek als het thema Zwarte Piet. Sinds 2011/2012 schudt het bestaansrecht van deze (al dan niet) als racistisch beoordeelde karikatuur op zijn grondvesten. Meer dan in de jaren zestig en tachtig van de vorige eeuw - toen de figuur ook al werd bekritiseerd - is het debat de laatste vijf jaar in alle hevigheid losgebroken. Belangrijker is echter dat deze discussie zich in razend tempo heeft verlegd naar een breder en (tot nu toe) aanhoudend debat over discriminatie op 
basis van ras-etniciteit in het algemeen. Mede geïnformeerd door ontwikkelingen in de Verenigde Staten, hebben aangrenzende vraagstukken zoals etnische profilering door politie, discriminatie op de arbeidsmarkt en (gebrek aan) diversiteit in de cultuursector zich naar de voorgrond gedrongen. In deze antiracismegolf duikt een kleine schare Nederlandse sociaalwetenschappers geregeld op om het debat van wetenschappelijke fundering te voorzien.

Twee wetenschappers in het bijzonder lijken het gezicht te zijn geworden van Nederlands onderzoek naar racisme. Ten eerste is dat emeritus hoogleraar genderstudies Gloria Wekker (Universiteit Utrecht), wiens White Innocence (2016) de gemoederen zowel in de media als in universiteitslokalen (zie Van den Berg et al. 2016) verhitte. Ten tweede is dat Philomena Essed, sinds 2005 hoogleraar Critical Race, Gender and Leadership Studies aan de Antioch University in de Verenigde Staten. Essed publiceerde in 1984 haar baanbrekende studie Alledaags Racisme. Op de achterflap van de originele uitgave valt te lezen: 'Alledaags Racisme zal veel discussie oproepen, en zo is het ook bedoeld. Het kan pijnlijk zijn - voor witte Nederlanders - te lezen hoe deze maatschappij omgaat met mensen van kleur. Het kan pijnlijk zijn voor de mensen van kleur te lezen hoe de realiteit er echt uitziet'. Die discussie kwam er: zowel in de pers als in de sociale wetenschap kon Alledaags Racisme rekenen op een zeer kritische ontvangst. Vervolgens publiceerde Essed het internationaal breed gelezen en geciteerde Understanding Everyday Racism: An Interdisciplinary Theory (1991; in het Nederlands uitgekomen als Inzicht in Alledaags Racisme). Daarna bleef het wat Nederland betreft ineens lang stil - het debat over (alledaags) racisme en wetenschappelijk onderzoek hiernaar, leek als een nachtkaars te zijn uitgegaan. Tot 2012, toen Zwarte Piet definitief zijn onschuld verloor. Essed publiceerde vervolgens samen met Isabel Hoving in 2014 de bundel Dutch Racism (met onder andere werk van Gloria Wekker). Dit jaar wordt dat opgevolgd door een heruitgave van Alledaags Racisme, 33 jaar na dato.

Gezien de relevantie van Esseds werk in de studie naar gender en racisme in Nederland en het feit dat zij vaak wordt opgevoerd als 'herontdekt' (Bahara 2016) in het Nederlandse (anti)racismedebat, is dit een uitstekend moment om met Philomena Essed in gesprek te gaan over haar werk en de aanhoudende relevantie hiervan. Want hoe hangt de hedendaagse politieke context van populisme en 'zeggen waar het op staat' samen met alledaags racisme? Daarnaast biedt dit gesprek de mogelijkheid om te reflecteren op de sociologische studie naar racisme in het algemeen. Onderwerpen zoals methodologie en alledaags/impliciet racisme, ont- 
hecht onderzoek en de rol van de (al dan niet activerende of activistische) sociologie, passeren de revue. Dit artikel vormt een verslag van het gesprek dat wij hierover voerden in september 2017.

\section{$2 \quad$ Alledaags racisme 33 jaar na Alledaags Racisme}

JS: In 1984 kwam Alledaags Racisme uit bij Feministische Uitgeverij Sara. Hoewel er relatief veel sociologische literatuur over ras en etniciteit bestond in de Verenigde Staten en het Verenigd Koninkrijk, was uw werk een van de eerste en weinige studies naar racisme in Nederland. Daarnaast betrof het een vergelijkende kwalitatieve studie tussen Nederland en Amerika - een unicum. $\mathrm{Nu}$, precies 33 jaar later, wordt het boek voor het eerst opnieuw uitgegeven. Het komt niet vaak voor dat een sociaalwetenschappelijk boek ruim dertig jaar nadat het origineel is uitgekomen ineens een herdruk krijgt. Waarom nu? En in hoeverre wijkt de nieuwe versie af van het origineel?

$P E$ : Hoewel er - inmiddels ook internationaal - in toenemende mate over racisme in Nederland wordt gesproken, is het verbazingwekkend hoe weinig er over is gepubliceerd in de wetenschap. Toen Van Gennep me vroeg voor een nieuwe editie van Alledaags Racisme, had ik enigszins gemengde gevoelens. Enerzijds werd ik er als wetenschapper even stil van. Zoiets overkomt meestal alleen de klassiekers of de grote schrijvers. Anderzijds was het absurd dat er 33 jaar later vraag was - vooral onder jonge kritische mensen - naar een herdruk omdat er in de tussentijd te weinig verder onderzoek had plaatsgevonden. Absurd in politieke zin. Midden jaren tachtig was er, deels naar aanleiding van mijn boek, een realisatie en zelfs een beleid van positieve actie vanuit lokale overheden die het probleem van rassendiscriminatie erkenden. Er was onder allerlei organisaties en progressieve bewegingen belangstelling voor mijn werk - dat ik bewust voor een breed publiek had geschreven - maar er was ook kritiek van collega-wetenschappers. Alledaags Racisme schudde aan gevestigde pilaren - er was iets aan de hand.

Eigenlijk kort daarna al, begin jaren negentig, werd het weer stil. Dominante spraakmakers scoorden met de opvatting dat er in Alledaags $R a$ cisme was overdreven en het onderwerp dus ook geen plek verdiende in de curricula. De backlash was heftig in haar gevolgen: een hoogopgeleide generatie werd beroofd van kennis over racisme. Als je als student of wetenschapper onderzoek wilde doen naar dit onderwerp moest je veelal 
terugvallen op buitenlandse literatuur. En dat was terug naar af: de uitgangspositie van waaruit $i k$ was begonnen. Mijn motivatie in de vroege jaren tachtig was juist de noodzaak van racisme-kritisch onderzoek in de lokale context omdat internationaal onderzoek niet altijd direct relevant is voor Nederland. Daarnaast wilde ik zichtbaar maken hoe racisme zich had genesteld in Nederland - niet alleen buiten onze grenzen. Mede door die backlash werd duidelijk dat ik mijn tijd kennelijk vooruit was; ik dacht destijds vijftien jaar, maar misschien was het wel dertig jaar. Als wetenschapper is pionier zijn mooi, maar voor het streven naar sociale rechtvaardigheid was de achterstand in het Nederlandse denken schokkend. Het lijkt erop dat we nu bezig zijn met een inhaalslag.

De nieuwe versie van mijn eerste boek heeft een toegevoegd voorwoord en een extra hoofdstuk over nieuwe ontwikkelingen op het gebied van racisme, met reflecties op het verleden gezien vanuit het heden. Verder heb ik slechts minimale aanpassingen gemaakt in de tekst om zoveel mogelijk de originele tekst te behouden.

Het intact houden van de inhoud heeft een reden: met de toenemende productiegerichtheid van onderwijs, waarin het continu produceren van nieuwe artikelen voorop staat, hebben veel studenten en docenten nauwelijks meer tijd om te lezen. De attentiespanne wordt hiermee kleiner. Ik zie ook steeds vaker dat studenten slechts artikelen van de laatste tien jaar lezen en klassieke, fundamentele werken overslaan. Dat is een probleem. Juist door die werken waar bepaalde ideeën in geaard zijn, zoals dat je in de sociologie in Weber, Durkheim en al die figuren werd gegrondvest, word je getraind in een geschiedenis van een denken. Ik zie dat verdwijnen aan de universiteit. Klassieke werken waarvan al gauw wordt gedacht dat die geen waarde meer hebben want 'die zijn al meer dan tien jaar oud'. Jazeker, er is meer historische dan actuele waarde in bepaald cijfermateriaal van de editie uit 1984, bijvoorbeeld over de omvang en aanwezigheid van bepaalde etnische groepen. Maar als je eenmaal daaraan sleutelt, is het corrigeer-einde zoek. Het heeft ook iets leerzaams om vanuit de 2017-lens te lezen over 1984 en de lezer te prikkelen om zelf te reflecteren op het verschil in tijdsgeest tussen toen en nu. Het behoud van originaliteit werkt omdat een bepaald concept, een bepaalde theorie, generaties lang toepasbaar kan zijn.

$J S:$ Veel ideeën en theorieën die worden besproken in Alledaags Racisme, zijn temidden van andere beschrijvingen terug te vinden in meer recente sociologische studies, met name Amerikaans onderzoek. Zo heeft u het over 'klein racisme', waarmee u doelt op subtiele maar veelvuldig voorkomende momenten van interactie waar huidskleur indirect een rol speelt. 
Zo horen Surinaams-Nederlandse vrouwen vaak 'waar kom je écht vandaan?' - ondanks dat zij in Nederland zijn geboren. Dergelijke mechanismes zijn vooral de laatste tien jaar besproken als 'micro-agressies' (Sue 2010), hoofdzakelijk in de psychologie. Tevens heeft u het over de ingewikkelde kwesties van het al dan niet negeren van huidskleur: kleurenblindheid. Ondanks dat de intentie van kleurenblindheid antiracistisch is, heeft deze vaak racistische uitwerkingen: iets dat de Amerikaanse socioloog Eduardo Bonilla-Silva later muntte als 'kleurenblind racisme' (2003). Dergelijke empirische bevindingen en uw theoretische duiding hiervan zijn veelal herkenbaar in later, internationaal werk. Hoe kijkt u hierop terug? $P E$ : Theorieën en het gedachtengoed daarachter zijn altijd in ontwikkeling, vaak tegelijkertijd op meerdere plaatsen, en dat geeft hier blijk van. Het viel me bij herlezen op dat ik het toen al had over de vermenging van seksisme en racisme. Ook speelde ik al met termen als 'seksueel racisme' of 'racistisch seksisme'. Wat ongeveer in dezelfde tijd de nu veelgebruikte term 'intersectionaliteit' is komen te heten (Crenshaw 1991) duid ik in Understanding Everyday Racism (1991) aan als 'gendered racism'. 'Alledaags racisme' is een tijdloos concept - een begrip als kleurenblind racisme geeft aan wat er verandert in de uitingen van alledaags racisme. Bonilla-Silva (2003) noemt het racisme zonder racisten, zelf spreek ik liever van racisme zonder ras-aanduiding. Dit verschijnsel kennen we in Europa nog beter dan in de VS. De normalisering van een westers-gedomineerde cultuurhiërarchie die zich legitimeert door vooral kleur of ras niet te noemen, ook al denk je dat en ook al zijn de gevolgen van dit uitsluitend-denken zichtbaar in de machtsstructuur van de samenleving - de idee-fixe dat er geen racisme kan zijn als er in termen van (etnische) cultuur wordt gesproken. Of recentelijk heel concreet: de formule 'Obama tijdperk = einde racisme', alsof het post-raciale tijdperk zou zijn aangebroken (vgl. Dawson en Bobo 2009). Het huidige regime leert helaas hoe krom die redenering was.

'Micro-agressies' omvatten wat ik de accumulatie noem van racistische praktijken waaruit alledaags racisme bestaat. Wat verandert zijn bepaalde uitingen daarvan. Maar het principe dat racisme geïntegreerd is in de manier waarop het alledaagse leven plaatsvindt en dat het - structureel ons hele leven beïnvloed, blijft gelden. Racisme omvat niet alleen bijzondere, expliciete momenten maar juist ook de repetitieve momenten in ons leven, de routine. En daar gaat alledaags racisme over. Racisme verandert mee met de aard van het alledaagse. Zo is alledaags racisme nu doorgedrongen in sociale media en voegt het zich naar de mogelijkheden die dit instrument te bieden heeft. 
De term micro-agressie is niet veel anders dan het begrip (negatieve) discriminatie; het kan voorkomen om welke reden dan ook en heeft daarmee een depolitiserend effect voor onderzoek. Dit is een voordeel als 'gender' of 'racisme' politiek taboetermen zijn, maar het nadeel is dat het beschrijvend blijft. Een verklarende theorie vormt een betere basis voor de ontwikkeling van interventie-instrumenten. Maar daarvoor is juist de macrocontext van gender, klasse, ras-etniciteit en disability belangrijk om te begrijpen op basis waarván agressies plaatsvinden, waarom, en hoe zich dat historisch ontwikkelde. Discriminatie is een meervoudig inzetbaar mechanisme en racisme als concept één van de specifieke ideologische, historische, culturele en structurele contexten waarin het instrumenteel is.

\section{Sociale media en rechts-populisme}

JS: Sociale media worden vaak aangewezen als drijvende kracht achter aanhoudende ongelijkheid en toenemende polarisering in de samenleving. Filterbubbels, nepnieuws en 'alternatieve feiten' staan tegenover een geglobaliseerde blik in een kosmopolitische wereld, met ongelimiteerde internationale en diverse communicatie. In hoeverre denkt $\mathrm{u}$ dat sociale media verantwoordelijk kunnen worden gehouden voor de huidige opleving van het publiek debat over de rol van ras-etniciteit in hedendaagse politieke tegenstellingen?

$P E$ : Dit geldt zowel voor de Nederlandse als de Amerikaanse situatie. De kritische communicatie van wat er aan racisme plaatsvindt - vooral ook bij politiegeweld en politieruwheid tegenover zwarte Amerikanen of any minority of color - verspreidt zich heel snel via sociale media. Maar uiteraard volgt de backlash daarop even snel. Zij die daarin stelling nemen, nemen geen blad meer voor de mond in het uiten van racisme. In Dutch Racism (2014) noemen wij dit - in navolging van een eerdere publicatie (Essed 2012) - 'entitlement racism' of 'eigengerechtigd racisme': racistische uitspraken en afbeeldingen uit naam van de vrijheid van meningsuiting. Deze vorm van racisme, hoewel niet per se veroorzaakt door, vindt wel voeding in de aard van sociale media, want de zenders schuilen vaak achter anonimiteit en men weet niet precies wie er leest. Als je iemand in het gezicht aankijkt en raciaal beschimpt, is het wat anders dan als je je richt op het stukje technologie van het beeldscherm voor je en je er geen voorstelling van hoeft maken dat het echte mensen zijn die lezen en voelen wat je over hen zegt. En, niet te vergeten, de sociale druk van snel reageren, hetgeen geen tijd laat voor doordacht reageren. 
Maar je noemt al de mooie paradox van sociale media. Het democratiseert wie gehoord kan worden en wie niet, dus verzet tegen racisme is ook veel zichtbaarder. Door de democratisering en de afwezigheid van duidelijke gedragsnormen en een tanend gevoel van morele verantwoordelijkheid voor de effecten van sociale media, kunnen de lelijke en slechtste kanten van mensen ongeremd naar boven komen. Toch zal ik sociale media niet ongenuanceerd de schuld geven. Het is gewoon een instrument. Een instrument dat op zichzelf de mogelijkheid geeft om het idee van vrijheid van meningsuiting heel breed en ongelimiteerd op te vatten. Eigengerechtigd racisme, nieuw voor deze digitale tijd van Web 2.0, zonder morele rem, is de bewuste keuze voor openlijk racistische uitspraken, terwijl men kan weten, anno nieuw millennium, dat het racisme is en ook dat niets geheim blijft. Er is ook geen 'onder ons gezegd en gezwegen' na het klikken op 'verzenden'. Hierover gaat het toegevoegde hoofdstuk in Alledaags Racisme.

$J S$ : Dat brengt ons tot een verdere reflectie op het heden: in het originele voorwoord van Alledaags Racisme schrijft u: 'wordt het woord racisme in Nederland niet angstvallig gereserveerd voor extreemrechts, zodat de overgrote meerderheid altijd naar 'anderen' kan wijzen in plaats van naar zichzelf?' (1984: 5). Als we een blik werpen op het aanhoudende populisme in Nederland en de Verenigde Staten, waar expliciet racisme een terugkeer lijkt te maken, denkt u dat deze stelling nog klopt voor 2017?

$P E$ : Het traditionele denken dat racisme uitsluitend bij extreemrechts plaatst, bestaat nog, met als ijkpunt de Tweede Wereldoorlog. Maar de generatie met een actieve herinnering aan de Tweede Wereldoorlog is uitstervende. Daarmee lijkt ook het morele geweten en het idee van 'dat nooit meer' te sterven - waarmee extreemrechts wellicht minder beangstigend overkomt. Het openlijke racisme baseert zich niet meer op een kwestie van 'niet weten'. Anno 2017 is er genoeg informatie beschikbaar over racisme waardoor 'niet weten' in zekere zin een keuze is geworden. De verruwing van public discourse betekent ook dat openlijk en ruw racisme alledaagser wordt. Immers, 'extreem' is een relatief begrip in relatie tot een substantiële midden- of meer gematigde groep die op andere manieren meedoet, toekijkt of tolereert, dat vervolgens geïnstitutionaliseerde vormen aanneemt. Maar het 'midden' verruwt ook, met als grote voorbeelden politici voor wie beledigen en mensonwaardige dingen zeggen hun signature is. In een kort artikel kan ik geen recht doen aan de complexiteit van het geheel. Er is een bijna cultachtige schare rond figuren die 'recht voor zijn raap' lelijke dingen zeggen, hetgeen appelleert aan presociale, diepegoïstische trekken om met niemand rekening te hoeven houden. 
Het huidige populisme is een huwelijk tussen het op zich democratisch en menselijk verlangen gezien en gehoord te worden en de onverzadigbare politieke machtshonger van de populist. De vaak dun-geïnformeerde 'ik vind, dus ik zeg' want 'het is mijn recht' mentaliteit van veel sociale media wordt opgepakt door politici die redeneren: 'zij vinden, ik zeg hen te begrijpen, dus hun stem komt mij toe'. Het cruciale verschil is dat je vanuit een burger of medebewonerspositie vooral je eigen waardigheid op het spel zet met 'haatpraat'. Het is hypocriet af te geven op de gewone burger als politici hen zijn voorgegaan in het presenteren van ongeinmeningen, onderbuikgevoelens en ongefundeerde zogenaamde feiten over etnische groepen, als ware het vanuit kennis van zaken. Fearmongering politici, die hun macht misbruiken vanuit een leidersrol, met grote verantwoordelijkheid en gevolgen voor de hele samenleving. In populisme spelen de opvatting en emotie van entitlement een sterk polariserende rol die mensen bevestigt in een monsterlijk net van angst voor elkaar: 'wat ik heb komt mij toe' en 'anderen misgunnen mij van alles'. Terwijl de meeste mensen eigenlijk veel liever zoeken naar verbinding. De stormachtige manier waarop sociale media technologisch de harten van miljarden mensen hebben veroverd kon juist ook plaatsvinden omdat daarmee 24/7 verbinding met anderen wordt gekoesterd.

Op dit moment zien we allerlei tendensen tegelijkertijd. In de Verenigde Staten is er de alt-right wier uitlatingen openlijk steun vinden bij de Ku Klux Klan. Dan is er de andere alt-right, die zegt dat hun opvattingen niks met racisme te maken hebben, 'het is de verdediging van ons land, onze cultuur, our way of life', een nativisme dat herkenbaar is in de Wilders-beweging en ander Nederlands rechts-populisme. Het heeft niks met racisme te maken, zeggen ze. Dan is er in de Verenigde Staten, net als in Nederland, een middenmoot die geneigd is om te ontkennen dat racisme een geïnstitutionaliseerd probleem is. Tegelijkertijd is er een groeiende beweging onder mensen van allerlei komaf die in actie komen tegen racisme en er openlijk voor willen staan dat iedereen gezien en gerespecteerd wordt in hun mens-zijn. In de Verenigde Staten loopt dit al langer, in Nederland is het groeiende. Het interessante is dat je dat vooral ook ziet onder de jongere generatie die deels opgroeit met meer vermenging van sociaaleconomische klassen, vooral op scholen (hoewel je ook wel gesegregeerde scholen hebt, maar dat is weer niet absoluut), in het straatbeeld, er is veel meer contact in de muziek - bij muziekfestivals is er én segregatie én meer contact -, dus dat is ook weer een gemengd beeld - kijk maar naar jouw onderzoek over de aanhoudende witheid in rockmuziek (Schaap 2015). Bovendien helpt internet om continu op de hoogte te zijn van wat 
er in de wereld gebeurt. De invloed van de Verenigde Staten op Nederland is gigantisch. Elke nieuwe trend in de VS wordt vertaald als relevant voor Nederland in termen van 'meedoen' of 'niet meedoen'. We zagen het al met de Occupy-beweging, Black Lives Matter en \#MeToo - overigens zijn de twee laatste bewegingen geïnitieerd door Afrikaans-Amerikaanse vrouwen, voortrekkers in actie tegen (de combinatie van) racisme en seksisme. In Nederland deels een copy-cat-verschijnsel, maar ook authentieke transnationale herkenning is van invloed en lijkt groter, directer en sneller zichtbaar geuit dan het dertig jaar geleden was.

\section{$4 \quad$ Epistemologie, methodologie en kritiek}

JS: Kortgeleden publiceerde dit tijdschrift een boekbespreking over de bundel Dutch Racism (Siebers 2016) waarin u een aantal kritieken ten deel vielen. Zo stelt Siebers:

[...] het boek [Dutch Racism, JS] put uit een veelvoud aan disciplines, behalve de sociologie. Dat is opmerkelijk omdat je sociologische data nodig hebt om de bovengenoemde verankering van processen van uitsluiting van migranten in structuren, instituties en discoursen te laten zien én in verband te brengen met racisme. De auteurs gaan er simpelweg vanuit dat de Nederlandse samenleving racistisch is om vervolgens reflecties en interpretaties te ontwikkelen, zonder de moeite te nemen om dat uitgangspunt aan te tonen (2016: 226).

Vergelijkbare kritieken werden destijds na de publicatie van Alledaags Racisme, 33 jaar geleden ook in de (geschreven) media (zie o.a. Brunt 1985) geuit. Deze kwestie lijkt vooral een epistemologische: u baseert zich in uw werk hoofdzakelijk op een hermeneutische, interpretatieve en ervaringsgerichte vorm van onderzoek, waar de critici niet door worden overtuigd. Kunt u hierop reflecteren?

PE: Ik ben ook in Alledaags Racisme en in Understanding Everyday Racism uitgegaan van de samenleving als racistisch (en bewust dus niet 'een samenleving bestaande uit racisten'). Als het een troost is voor Siebers: mijn theoretische benadering en methodologie zijn heel positief ontvangen door niet geringe sociologen als Joe Feagin, Patricia Hill Collins en Michele Lamont. Mijn werk is in meer dan tien landen toegepast. David R. Williams, expert in sociologie en public health, destijds aan de University of Michigan en nu, net als Lamont, aan Harvard, kwantificeerde (mijn) kwa- 
litatief geselecteerde ervaringen van alledaags racisme voor survey-onderzoek, onlangs ook toegepast om self-reported raciaal-etnische discriminatie te kunnen meten in relatie tot bijvoorbeeld een gevoel van gezondheid en welzijn (Sharif et al. 2011). Dit zijn allemaal sociologen die zich uitgebreid hebben verdiept in (alledaags) racisme - zie ook Lamonts studie Getting Respect (2016). Het wordt vaak vergeten dat racismestudies een vakgebied op zich is.

Het eerste onderzoek dat ik deed in 1984 en ook het geheel nieuwe onderzoek voor Understanding Everyday Racism - dus overigens geen enkel gerecycled interview uit 1984 zoals ik weleens heb horen beweren - was norm-doorbrekend op verschillende niveaus. Het eerste onderzoek betrof wat Nederland betreft bijna alleen laagopgeleide vrouwen. In het tweede onderzoek wilde ik de mythe doorprikken dat educatie de sleutel is tot acceptatie en interviewde uitsluitend hoogopgeleide vrouwen. Ik wilde verder geen observaties doen, maar luisteren naar omschrijvingen van hetgeen reeds was voorgevallen. Maar het positivisme predikte observaties. Mijn stelling was: 'Waarom weer een sociaal experiment opzetten waarbij zwarte mensen opnieuw door racisme heen gaan, omdat de wetenschapper meent dat "het pas waar is als $i k$ het zelf observeer"? Maar als anderen het hebben gezien of beleefd, dan kan het niet gelden.' Dit stuitte mij ethisch tegen de borst. En overigens, wat is menig survey anders dan selfreported meningen en/of ervaringen? Ik heb dus geput uit de ervaringen en kennis die je ontwikkelt als je keer op keer met hetzelfde wordt geconfronteerd. Het blijkt kennis die gerelateerd is aan emotie, maar wel rationele paden van interpretatie volgt. Het is kennis die betekenis geeft aan je alledaagse leven en die je helpt in het alledaagse leven om staande te blijven. Die kennis heb ik aangeboord, hetgeen destijds ongebruikelijk was in de sociologie. En dan nota bene van vrouwen en dan nota bene nota bene - de ervaringskennis van zwarte vrouwen. Ik deed allemaal dingen die totaal niet gepast waren in de sociale wetenschappen. Het is nu misschien moeilijk voor te stellen, maar dat was allemaal nieuw.

Verder was er het epistemologische spanningsveld van 'wiens kennis geldt nu eigenlijk?', 'waar vergaar je de kennis?' en 'wiens stem geldt?' Verder waren er ook nog de politieke vragen: 'naar welke stemmen heb je geluisterd?', 'wie is de onderzoeker?' Dus mijn werk was traditie-doorbrekend op vele manieren, niet alleen methodologisch. Het principe van overdraagbaarheid van bevindingen - transferibility - wat voor veel kwalitatief onderzoek geldt, stond nog in de kinderschoenen. Ik beoogde niet om positivisten te overtuigen, maar een raamwerk te bieden waarin velen 
zich konden herkennen. De conceptuele familie van mijn werk is onder meer (deels) herkenbaar in de tegenwoordig veelvuldig toegepaste Grounded Theory en Situational Analysis. In haar lijvige boek New Racism (2010) over methoden van onderzoek op het gebied van racisme wijdt methodoloog Norma Romm een uitvoerig, kritisch hoofdstuk aan mijn methodologie, waar studenten wat mee kunnen.

Evenmin was mijn doel aan te tonen dat de Nederlandse samenleving racistisch is. Ongelijkheidsstructuren lopen via raciale en etnische lijnen. En die zijn meer dan zichtbaar in Nederland. Dus ja, waar begin je dan? Dat is ook exact de reden waarom wij Dutch Racism in een ander paradigma hebben verankerd, namelijk dat in Nederland, net als elke andere westerse samenleving, en daar niet alleen, racisme in het systeem verweven is. Vanuit die positie wilden we onderzoeken of er karakteristieken zijn voor Nederlands racisme. Die zijn er, in lijn met mijn veronderstelling dat racisme zich voegt naar de aard van de samenleving. Deels maakt zij die aard, maar het voegt zich ook toe naar de instrumenten die beschikbaar zijn in de samenleving.

Het klopt dat veel van deze complexe fenomenen hoofdzakelijk kwalitatief zijn te ondervangen. Deels is het wél in cijfers uit te drukken. Maar los van het cijfermateriaal: sommige dingen kun je niet in cijfers laten zien omdat ze kwalitatief van aard zijn.

JS: Sinds de late jaren negentig wordt er steeds meer onderzoek gedaan naar racisme en discriminatie door naar impliciete factoren te kijken, met name door het gebruik van de Implicit Association Test (IAT; Greenwald et al. 1998), die in staat zou zijn om impliciete associaties op basis van rasetniciteit en zelfs 'racial bias' te ontaarden. Potentieel dus een manier om dergelijke kritieken methodologisch te adresseren?

$P E$ : Elke methodologie heeft zijn plek. Ik hecht veel waarde aan kwantitatief onderzoek omdat dat bepaalde dingen aantoont en laat zien die je met kwalitatief onderzoek niet kunt laten zien en vice versa. Het onderzoek naar impliciet racisme bevestigt wat we vanuit het feminisme en onderzoek naar racisme al veel langer wisten. Wat IAT-onderzoek niet goed laat zien is waarom die bias nou net daarover is en niet over iets anders. En hoe impliciet is het nu eigenlijk? Want het wordt aangenomen als impliciet omdat men het niet expliciet zegt. Maar is het ook impliciet voor de handelende mens? Waarom kleur, gender, religie - waarom zijn dat de associaties die een opvallendere rol spelen? Wat is het dat automatisch wordt getriggerd in de kleurherkenning van 'oh, die is zwart dus die is anders' of 'oh die is wit, dus ik herken iets van mezelf. Wat is het dat je meent te 
herkennen? En daarin kan een laag zijn die heel erg onbewust is. Er zijn ook lagen die redelijk in ons bewustzijn liggen. Dus het is veel complexer dan sociaalpsychologische onderzoeken kunnen laten zien. Maar elke stap telt, dus het 'unconscious bias'-onderzoek is belangrijk, het heeft een zichtbaar makende plek in de racismetheorie. Tegelijkertijd moet daarmee niet de aandacht voor de onderliggende machtsstructuren verdwijnen, anders krijg je zoiets van 'I'm okay, you're okay; I'm biased, you're biased' - 'zo werken de hersenen nu eenmaal'.

In Alledaags Racisme intrigeerde mij de vraag hoe weet je of iets racisme is?' Ik vermoedde dat iets intuïtief als racisme herkennen neerkomt op razendsnel gebruik maken van kennis op basis van socialisatie en de herhaaldelijke confrontatie met vooroordelen en discriminatie. Onlangs kwam ik bevestigend onderzoek tegen over intuïtie als snelle activering van emotionele en andere accumulatieve kennis (Lufityanto et al. 2016). Deze intuïtieve kennis, zo stellen de onderzoekers, is vooral belangrijk in het nemen van beslissingen in situaties van onzekerheid. Dat is ten voeten uit vaak het geval bij racisme, omdat het wordt ontkend: 'zo heb ik het niet bedoeld, je bent overgevoelig, weet je wel hoe erg het is te worden beschuldigd van racisme,' enzovoorts. In Alledaags Racisme heb ik een eerste poging gedaan intuïtieve kennis over racisme te operationaliseren door in detail te kijken naar de gemaakte vergelijkingen en de geactiveerde kennis en bronnen die mensen gebruiken om te bepalen of iets wel of niet racisme is. Dit heb ik uitgebreider en, naar ik hoopte, theoretisch meer solide, kunnen onderzoeken in Understanding Everyday Racism. Cognitietheorie heeft mij dus altijd al gefascineerd.

\section{Wetenschappers op de barricade}

$J S$ : Als wetenschapper heeft $\mathrm{u}$ een strijdbare houding. $\mathrm{U}$ staat hierin niet alleen: in de critical race studies (bijv. Delgado en Stefancic 2017; Twine en Warren 2000) is een lange traditie van activistische wetenschap, of wetenschap met een duidelijke normatieve stellingname. Ziet u uzelf als activistisch wetenschapper? En, kijkende naar het idee van waardevrije wetenschap zoals bijvoorbeeld gepropageerd door Max Weber in Wetenschap als beroep (2012 [1919]), ziet u waardeoordelen in de wetenschap als probleem of als mogelijkheid?

PE: Waardevrije wetenschap... zo twintigste-eeuws. Zijn er echt nog mensen die dat denken? Qua positionering zie ik mezelf als een social justice 
scholar. Mijn wetenschappelijke drijfveer is niet alleen, maar wel expliciet ook, het verlangen bij te dragen aan sociale rechtvaardigheid. Ik wil handvatten bieden voor het begrijpen en tegengaan van onrechtvaardigheid, maar de mensen vrijlaten het op te pikken of niet. Als je je kunt laten inspireren door wat ik onderzoek en hoe ik dat doe: prachtig. Maar de toepassing is een eigen keuze. In die zin geloof ik in de weberiaanse houding van wetenschappelijke afstandelijkheid. Toen ik studeerde was hij overigens mijn favoriet onder de klassieken.

$J S$ : De laatste jaren is er relatief veel activistisch werk geproduceerd over racisme. In Nederland zijn dat het eerder genoemde White Innocence (Wekker 2016), Sunny Bergmans documentaire Wit is ook een kleur (2016), Anousha Nzume's Hallo witte mensen (2017). Hoe denkt u dat Alledaags Racisme zich daartoe verhoudt?

$P E$ : Ik meen te begrijpen dat die auteurs zich mede hebben laten inspireren door Alledaags Racisme - en dat zeg ik met enige schroom. Bij herlezen na tig jaren besefte ik waarom Uitgeverij Van Gennep het wilde herpubliceren. Er staat zoveel in wat nog zo geldig, nijpend of schrijdend is. Interessant hierbij is dat de ervaringen van vrouwen van Surinaamse komaf, die centraal staan in het boek, deels onveranderd zijn, zoals blijkt uit een onderzoek van Dienke Hondius en haar studenten (2014), maar ook deels zijn verschoven naar nieuwe groepen in de samenleving. Er is nu ook een generatie die behoefte heeft om te begrijpen waar hun kritisch denken vandaan komt. Dat heb ik zelf ook gehad. Het was een enorm aha-moment toen ik buitenlandse literatuur las en dacht 'ik ben niet gek, het klopt dat racisme een structureel verschijnsel is in Nederland'. Dit groeiend bewustzijn en zelfvertrouwen in de eigen kritische analyses komt niet alleen vanuit 'zwarte' Nederlanders. Het is een grotere, gemengde groep. Tegelijkertijd weet ik ook dat de verworvenheden van het ene op het andere jaar ineens kunnen verdwijnen; een backlash ligt altijd op de loer.

\section{$6 \quad$ Een nieuwe generatie onderzoekers}

JS: Uit die groeiende groep kritische denkers komen vast ook nieuwe onderzoekers voort. Wat zou u studenten en jonge onderzoekers die zich willen buigen over deze materie willen meegeven?

$P E$ : Allereerst - voor hen die nog geloven in waardevrij onderzoek - dit is niet het soort onderzoek dat je wilt doen. Het is niet mogelijk om racisme te bestuderen en te pretenderen dat je er geen mening over hebt; neutraal staan ten opzichte van de legitimiteit en morele status van racisme. Het is 
een duidelijke stellingname en dat is soms lastig. Zelf ben ik ongeacht de backlash altijd doorgegaan. Contra-intuïtief gebeurt het volgende: dieper in de materie duiken, veel erover lezen en onderzoeken minimaliseert het gevoel van ongemak over het onderwerp en helpt juist meer afstand te nemen. Ik neem racisme ook niet persoonlijk, want het is ook nooit persoonlijk bedoeld - het is een groepsconflict.

Ten slotte is het belangrijk te herhalen dat een specifieke vorm van dominantie - racisme in dit geval - niet lost staat van andere vormen van vernederingen die beogen mensen in hun waardigheid aan te tasten. Sociale mechanismen die werken in termen van racisme werken ook in andere velden. Er is wat mij betreft geen hiërarchie van structurele uitsluitingen. Er zijn slechts verschillende vormen en geschiedenissen van groepsconflict. Uiteindelijk gaat het om de erkenning dat een ieder gelijke waarde heeft als mens. Mijn huidige studie naar een 'cultuur van waardigheid' heeft iets universeels. Maar tegelijkertijd kun je gelijkwaardigheid alleen goed begrijpen als je ook inzicht hebt in de specifieke manieren waarop mensen worden gedehumaniseerd, gemarginaliseerd of vernederd.

\section{Literatuur}

Bahara, H. (2016) De revanche van de antiracismewetenschap. De Volkskrant, 2 juli, https:// www.volkskrant.nl/voorpagina/de-revanche-van-de-antiracismewetenschap a4332202/.

Berg, M. van den, E. Berkvens, C. Chivers, B. Heertje en M. Smit (2016) 'Racisme is geen ver-vanmijn-bed-show meer': Een gesprek over de lessen uit Gloria Wekkers White Innocence (2016). Sociologie, 12(3): 379-388.

Bonilla-Silva, E. (2003) Racism without racists: Color-blind racism and the persistence of racial inequality in America. Lanham: Rowman and Littlefield.

Brunt, E. (1985) Ik ben racist, jij bent racist. NRC Handelsblad, 12 januari, p. 27.

Crenshaw, K. (1991) Mapping the margins: Intersectionality, identity politics, and violence against women of color. Stanford Law Review, 1241-1299.

Dawson, M.C. en L.D. Bobo (2009) One year later and the myth of a post-racial society. Du Boise Review: Social Science Research on Race, 6(2): 247-249.

Delgado, R. en J. Stefancic (2017) Critical race theory: An introduction [derde editie]. New York: New York University Press.

Essed, P. (1984) Alledaags racisme. Amsterdam: Feministische Uitgeverij Sara.

Essed, P. (1991) Understanding everyday racism. An interdisciplinary theory. London: Sage.

Essed, P. (2013) Entitlement racism: License to humiliate. European network against racism, recycling hatred: Racism(s) in Europe today.

Essed, P. (2017 [1984]) Alledaags racisme (derde herziene druk). Amsterdam: Van Gennep.

Essed, P. en I. Hoving (red.) (2014) Dutch racism. Amsterdam: Rodopi.

Greenwald, A.G., D.E. McGhee en J.L. Schwartz (1998) Measuring individual differences in impli- 
cit cognition: the Implicit Association Test. Journal of Personality and Social Psychology, 74 (6): 1464-1480.

Hondius, D. (2014) Black Dutch voices: Reports from a country that leaves racism unchallenged. Thamyris/Intersecting: Place, Sex and Race, 27(1): 273-293.

Lamont, M., G.M. Silva, J.S. Welburn, J. Guetzkow, N. Mizrachi, H. Herzog en E. Reis (2016) Getting respect: Responding to stigma and discrimination in the United States, Brazil and Israel. Princeton: Princeton University Press.

Lufityanto, G., C. Donkin en J. Pearson (2016) Measuring intuition: nonconscious emotional information boosts decision accuracy and confidence. Psychological science, 27(5): 622-634.

Nzume, A. (2017) Hallo witte mensen. Amsterdam: Amsterdam University Press.

Romm, N. (2010) New racism: Revisiting researcher accountabilities. New York: Springer Science and Business Media.

Schaap, J.C.F. (2015) Just like Hendrix: Whiteness and the online critical and consumer reception of rock music in the Unites States, 2003-2013. Popular Communication, 13(4): 272-287.

SCP (2016) Integratie in zicht? De integratie van migranten in Nederland op acht terreinen nader bekeken. Denk Haag: Sociaal en Cultureel Planbureau

Shariff-Marco, S., N. Breen, H. Landrine, B.B. Reeve, N. Krieger, G.C. Gee en B. Liu (2011) Measuring everyday racial/ethnic discrimination in health surveys: How best to ask the questions, in one or two stages, across multiple racial/ethnic groups? Du Bois Review: Social Science Research on Race, 8(1): 159-177.

Siebers, H. (2016) De pot verwijt de ketel... Hoe antiracisme de analyse van racisme een slechte dienst bewijst. Sociologie, 12(2): 225-230.

Sue, D.W. (2010) Microaggressions in everyday life: Race, gender, and sexual orientation. New Jersey: Wiley.

Twine, F.W. en J.W. Warren (2000) Racing research, researching race: Methodological dilemmas in critical race studies. New York: New York University Press.

Weber, M. (2012 [1919]) Wetenschap als beroep. Nijmegen: Vantilt.

Wekker, G. (2016) White innocence: Paradoxes of colonialism and race. Durham: Duke University Press.

\section{Over de auteurs}

Julian Schaap is cultuursocioloog en als docentpromovendus werkzaam aan de Afdeling Kunst- en Cultuurwetenschappen van de Erasmus Universiteit Rotterdam. Daar doet hij (onder andere) onderzoek naar de samenhang tussen sociale ongelijkheid en smaakvoorkeuren in populaire muziek.

E-mail: j.schaap@eshcc.eur.nl

Philomena Essed is cultureel antropoloog en hoogleraar Critical Race, Gender and Leadership Studies aan de Antioch University, Verenigde Staten. Zij promoveerde in 1990 cum laude aan de Universiteit van Amsterdam. De daaruit voortgekomen publicatie Understanding Everyday Racism (1991), in het Nederlands uitgebracht als Inzicht in Alledaags Racisme 
(1991), behoort nog steeds tot een van de internationale standaardwerken in de studie naar ras-etniciteit en racisme. Naast verschillende boeken heeft Essed tientallen andere publicaties op haar naam staan, ontving zij verscheidene eredoctoraten (Universiteit van Pretoria in Zuid-Afrika, 2011, Umeå Universiteit in Zweden, 2015) en werd zij in 2011 benoemd tot Ridder in de Orde van Oranje-Nassau.

E-mail: essed@antioch.edu 